\title{
Greenland ice sheet surface temperature, melt and mass loss: 2000-06
}

\author{
Dorothy K. HALL, ${ }^{1}$ Richard S. WILLIAMS, Jr, ${ }^{2}$ Scott B. LUTHCKE, ${ }^{3}$ \\ Nicolo E. DIGIROLAMO ${ }^{4}$ \\ ${ }^{1}$ Cryospheric Sciences Branch, Code 614.1, NASA Goddard Space Flight Center, Greenbelt, Maryland 20771, USA \\ E-mail: dorothy.k.hall@nasa.gov \\ ${ }^{2}$ US Geological Survey, Woods Hole Science Center, 384 Woods Hole Road, Woods Hole, Massachusetts 02543-1598, USA \\ ${ }^{3}$ Planetary Geodynamics Laboratory, Code 698, NASA Goddard Space Flight Center, Greenbelt, Maryland 20771, USA \\ ${ }^{4}$ Science Systems and Applications, Inc., Lanham, Maryland 20706, USA
}

\begin{abstract}
A daily time series of 'clear-sky' surface temperature has been compiled of the Greenland ice sheet (GIS) using $1 \mathrm{~km}$ resolution moderate-resolution imaging spectroradiometer (MODIS) landsurface temperature (LST) maps from 2000 to 2006. We also used mass-concentration data from the Gravity Recovery and Climate Experiment (GRACE) to study mass change in relationship to surface melt from 2003 to 2006 . The mean LST of the GIS increased during the study period by $\sim 0.27^{\circ} \mathrm{Ca}^{-1}$. The increase was especially notable in the northern half of the ice sheet during the winter months. Meltseason length and timing were also studied in each of the six major drainage basins. Rapid ( $<15$ days) and sustained mass loss below $2000 \mathrm{~m}$ elevation was triggered in 2004 and 2005 as recorded by GRACE when surface melt begins. Initiation of large-scale surface melt was followed rapidly by mass loss. This indicates that surface meltwater is flowing rapidly to the base of the ice sheet, causing acceleration of outlet glaciers, thus highlighting the metastability of parts of the GIS and the vulnerability of the ice sheet to air-temperature increases. If air temperatures continue to rise over Greenland, increased surface melt will play a large role in ice-sheet mass loss.
\end{abstract}

\section{INTRODUCTION}

The Greenland ice sheet (GIS) contains enough mass to produce a rise in eustatic sea level of $\sim 7.0 \mathrm{~m}$ if the ice were to melt completely (Gregory and others, 2004). Even small increases (centimeters) in sea level would have important economic and societal consequences in the world's major coastal cities (Bindoff and others, 2007; Rowley and others, 2007). If the well-documented warming continues in the Arctic (ACIA, 2005; Richter-Menge and others, 2006; IPCC, 2007), melting of the GIS is likely to accelerate, augmenting the ongoing rise in sea level. Extensive melt and mass loss on the GIS have been documented in recent years (Krabill and others, 2000; Abdalati and Steffen, 2001; Joshi and others, 2001; Nghiem and others, 2001; Steffen and others, 2004; Comiso, 2006b; Luthcke and others, 2006; Rignot and Kanagaratnam, 2006; K. Steffen and R. Huff, http://cires. colorado.edu/science/groups/steffen/greenland/melt2005/). Mass loss occurs through surface melting, percolation through the ice, and subglacier runoff, and when land-based ice calves into the sea. Meltwater that reaches the base of the ice sheet lubricates the ice-bedrock interface, increasing the velocity of outlet glaciers and thus accelerating mass loss (Zwally and others, 2002; Joughin and others, 2004; Rignot and Kanagaratnam, 2006; Steffen and others, 2006).

Model results indicate that an annual or summer temperature rise of $1{ }^{\circ} \mathrm{C}$ on the GIS will increase ice melt by $20-50 \%$ (Oerlemans, 1991; Braithwaite and Olesen, 1993; Ohmura and others, 1996; Janssens and Huybrechts, 2000; Hanna and others, 2005). The surface temperature, $T_{\mathrm{s}}$ of the GIS is influenced strongly by near-surface air temperature. Melting in areas that experience sustained increases in air temperature of $\geq 0^{\circ} \mathrm{C}$, and in areas where residual water content of the firn has been exceeded, will lead to a negative ice-sheet mass balance over large areas of the ice sheet if there is an excess of melt compared with the previous winter's snowfall. Therefore, the $T_{\mathrm{s}}$ of the GIS is one of the most important ice-sheet parameters to study for forecasting changes in the mass balance of the ice sheet.

Various satellite and airborne remote-sensing and groundbased measurements may be used to assess the mass balance of the GIS. In this paper, however, we focus on clear-sky surface temperature or land-surface temperature (LST) from 2000 to 2006 derived from the moderate-resolution imaging spectroradiometer (MODIS) flown on NASA's Terra satellite, and gravimetry data from the Gravity Recovery and Climate Experiment (GRACE) for the period from July 2003 to July 2006. Specifically, we: (1) analyze clear-sky LST and melt variability in each of the six major drainage basins of the GIS to look for patterns and short-term trends in $T_{\mathrm{s}}$ that may be relevant to observed changes in the Arctic; (2) calculate interannual melt-season timing and duration; and (3) analyze the relationship between initiation and cessation of surface melt from MODIS LST data, and initiation and cessation of mass loss using GRACE gravimetry data.

\section{BACKGROUND}

Surface temperatures on the GIS have been studied on the ground using automatic weather station (AWS) data from the Greenland Climate Network (GC-Net) (Steffen and Box, 2001; Box, 2002) and from analysis of satellite sensor data (see, e.g., Key and Haefliger, 1992; Haefliger and others, 1993; Stroeve and Steffen, 1998; Shuman and others, 2001; Comiso and others, 2003; Comiso, 2006b). Using Advanced Very High Resolution Radiometer (AVHRR) weekly maps at $6.25 \mathrm{~km}$ resolution from 1981 to 2005, Comiso (2006b) 
showed that warming predominates in the western Arctic, North America, Greenland and much of Europe, while a cooling of the climate is observed elsewhere, such as in Russia. He also showed that the overall temperature trend poleward of $60^{\circ} \mathrm{N}$ is $0.72 \pm 0.10^{\circ} \mathrm{C}$ per decade, with an increase in surface temperature of the GIS of $1.19 \pm 0.20^{\circ} \mathrm{C}$ per decade, or an average of $\sim 0.12^{\circ} \mathrm{Ca}^{-1}$ between 1981 and 2005, with a possible $3+$ day increase in the length of the melt season during the same period for the GIS. Recently, Hall and others (2006) showed the relationship between LST and icesheet mass balance using the 8 day composite, $5 \mathrm{~km}$ resolution MODIS LST product (MOD11C2) developed by Wan and others (2002). Mean LST of the GIS was shown to be highest in 2002 and 2005, in agreement with results of K. Steffen and R. Huff (http://cires.colorado.edu/steffen/ greenland/melt2005/), who noted unusually extensive melt of the ice sheet in 2002 and 2005 from analysis of passive and active microwave data. Similarly, years of relatively less surface melt, 2000 and 2001, had lower mean LSTs (Hall and others, 2006).

Although recent accelerated melting of the Arctic (Comiso, 2006a) and the GIS has been measured (Abdalati and Steffen, 2001; Nghiem and others, 2001; Krabill and others, 2004; Chen and others, 2006; Rignot and Kanagaratnam, 2006; Velicogna and Wahr, 2006) and modeled (Box and others, 2006), longer-term warming has not shown a consistent trend. Hanna and Cappellen (2003) showed a significant cooling trend $\left(-1.29^{\circ} \mathrm{C}\right.$ over a 44 year period (1958-2001)) for eight stations in coastal southern Greenland. Box (2002) showed spring and summer cooling in southern Greenland, a $2-4{ }^{\circ} \mathrm{C}$ warming in western Greenland, and a possible $1.1^{\circ} \mathrm{C}$ warming at the ice-sheet summit for the period 1991-2000. Steffen and others (2006) show a winter air-temperature increase of up to $0.5^{\circ} \mathrm{Ca}^{-1}$ over the last 15 years in the western GIS.

Much of the observed $T_{\mathrm{S}}$ variability on the GIS is linked to the North Atlantic Oscillation (NAO) (Appenzeller and others, 1998; Mote, 1998a, b; Huff and Steffen, 2006), seaice extent, and large explosive volcanic events (e.g. Pinatubo, Philippines, in June 1991) (Box, 2002). In particular, the NAO is highly correlated with surface-melt extent (Mote, 1998a).

The NAO is usually described as an oscillation (or 'seesaw') in the strength of the Icelandic low and the Azores high. The Icelandic low is a semi-permanent center of low atmospheric pressure found over the Atlantic Ocean between Iceland and southern Greenland, as measured at Stykkishólmur, Iceland, and the Azores high is a semipermanent high-pressure region found over the Atlantic Ocean at about $30^{\circ} \mathrm{N}$ latitude in winter (Ponta Delgada (Azores), Lisbon (Portugal) and Gibraltar have all been used as the southern station). The positive NAO index phase shows a stronger than usual subtropical high and a deeper or stronger than usual Icelandic low. The positive phase of the $\mathrm{NAO}$ is associated with an increased north-south pressure difference and results in more and stronger winter storms crossing the Atlantic Ocean on a more northerly track, and in colder and drier winters in Greenland (Hurrell, 1995; Rogers, 1997). The negative NAO index phase is characterized by a weak subtropical high and a weak Icelandic low. The reduced pressure gradient results in fewer and weaker storms crossing on a more west-east path, which permits milder winter temperatures in Greenland (http:// www.atmosphere.mpg.de/enid/77d9810278d8243047762d 9afac0ae3b,55a304092d09/193.html). The NAO is better characterized as an annular mode, and is increasingly being referred to (at least in the dynamical literature) as the Northern Annular Mode (NAM), or a north-south shift in atmospheric mass between the polar regions and the midlatitudes, because it is not a true 'oscillation' (Thompson and others, 2003; D.W.J. Thompson, http://atmos.colostate.edu/ ao/introduction.html. Thus, in the remainder of this paper, we refer to the NAM instead of the NAO.

The correspondence between the rise in summer temperatures in coastal locations of the GIS, starting about 1995, and increased glacier activity suggests that warming has a nearly immediate effect on the velocity of outlet glaciers, and that modest $\left(1^{\circ} \mathrm{C}\right)$ increases in temperature can lead to large changes in the discharge of glacier ice to the ocean, most likely through the mechanism of transferring surface melt to the bed of the ice sheet through moulins and crevasses (Zwally and others, 2002). This is contrary to earlier hypotheses that an ice sheet may take tens or hundreds of years to respond to short-term air-temperature changes (see, e.g., Sugden and John, 1976).

Many studies have shown mass-balance or melt characteristics in specific parts or basins of the GIS. Abdalati and Steffen (2001) showed summer melt extent for different topographically defined climate zones: a 21 year time series shows a positive melt trend of $1 \% \mathrm{a}^{-1}$. Zwally and others (2005) and Luthcke and others (2006) reported the greatest mass loss in the southeastern part of the GIS. Rignot and Kanagaratnam (2006) showed that the velocity of outlet glaciers has increased, especially in the east-central, southern and western parts of the ice sheet, and is accompanied by accelerated retreat and thinning of the glacier termini and a corresponding increase in seismic activity related to the accelerated flow of outlet glaciers (Ekström and others, 2006).

Using gravimetry data from the GRACE satellite, Luthcke and others (2006) found a significant mass loss of the GIS in drainage basins 3 (east-central), 4 (southeast) and 6 (northwest), with basin 4 (southeast GIS) dominating the mass loss for a 2 year period (2003-05); basins 1, 2 and 5 were nearly in balance. Luthcke and others (2006) also reported a mass gain of $54 \mathrm{Gta}^{-1}$ at elevations $>2000 \mathrm{~m}$ and a loss of $155 \mathrm{Gta}^{-1}$ at elevations $<2000 \mathrm{~m}$, with an overall net mass loss of the GIS from 2003 to 2005 of $101 \pm 16 \mathrm{Gta}^{-1}$. Using aircraft laser and satellite radar altimetry, Krabill and others (2000, 2004), Thomas and others (2001) and Zwally and others (2005) reported a thinning of the GIS at elevations below $\sim 2000 \mathrm{~m}$ around the margins and a thickening at elevations greater than $\sim 2000 \mathrm{~m}$. Johannessen and others (2005) found an increase in surface elevation of the ice sheet above $1500 \mathrm{~m}$ of $6.4 \pm 0.2 \mathrm{~cm} \mathrm{a}^{-1}$. Zwally and others (2005) reported that the GIS was in approximate mass balance or perhaps had a slightly positive mass balance. Krabill and others (2004) documented an acceleration of mass loss from 1997 to 2003, compared with the period ranging from 1993/ 94 to $1998 / 99$, at elevations $<2000 \mathrm{~m}$, and mass-balance equilibrium above $\sim 2000 \mathrm{~m}$.

In summary, there appears to be near-consensus from recent works that there is a small net mass loss of the GIS, with a general thinning at lower elevations (below $\sim 2000 \mathrm{~m}$ ) and a thickening at the higher elevations (>2000 m), with the southeastern parts of the ice sheet experiencing the greatest mass loss. This has been determined by analysis of data from sensors that record energy from different parts of the electromagnetic spectrum. 


\section{DATA AND METHODOLOGY}

For the present work, we use the $1 \mathrm{~km}$ pixel resolution MODIS LST standard daily product (MOD11A1), discussed in detail in Wan and others (2002), from Collection-4 reprocessing which provides surface temperatures over the Earth's land areas under clear-sky conditions. A cloud mask is generated from another MODIS standard product, MOD35 (Ackerman and others, 1998; Platnick and others, 2003), and is an input to the MOD11A1 LST algorithm.

For each day from 24 February 2000 to 31 December 2006, a $1 \mathrm{~km}$ resolution map of LST of the GIS was compiled by digitally 'mosaicking' MOD11A1 granules (or scenes) onto an Albers equal-area map of Greenland. (MODIS acquired its first image data on 24 February 2000 from the Terra satellite and has provided data nearly continually since then.)

Mean melt-season LST was calculated for the entire ice sheet, and within each of its six major drainage basins (as defined by Zwally and others (2005) (Fig. 1)), during the period of most active surface melt, from 30 April/1 May to 12/13 August (days 121-225) of each year (2000-06). (Date varies depending on whether the year was a leap year.) We also computed mean annual $T_{\mathrm{s}}$ from Steffen and Box (2001) and Cassano and others (2001).

To develop melt-frequency maps, we define 'melt' as any pixel for which the LST was $\geq 0^{\circ} \mathrm{C}$. We also calculated leastsquares-fit lines for melt-season length, timing (start and end) and duration in each of the six major drainage basins of the GIS for the 7 year study period (2000-06). We define the beginning of the melt season as the first 2 days of consecutive melt, and the end of the melt season as the last 2 days of consecutive melt. For example, if days 1 and 3 experience melt and day 2 is cloudy, there are 2 days of consecutive melt according to our definition. $T_{\mathrm{s}}$ is usually higher under cloud cover than under clear skies because of strong radiational cooling from the snow-ice surface under clear skies that does not occur when skies are cloudy. Thus, the assumption is that the LST will remain at $0^{\circ} \mathrm{C}$ (or above; see section 5 for a discussion of this) on the cloudy days between the days with melt as determined from the LST data.

We also compared the melt onset and duration with GRACE local mass-concentration (or mascon) data, to study the relationship of surface melt to ice-sheet mass loss. GRACE denotes the twin satellites launched in March 2002 that are flying in formation about $220 \mathrm{~km}$ apart; changes in the distance between the satellites are used to make detailed measurements of the Earth's gravity field, enabling masschange studies of the GIS that result from precipitation (mass gain) and ablation or iceberg calving (mass loss). The lead satellite, for example, will be pulled away farther from the trailing satellite when it passes above an area of larger mass concentration. The resolution is fine enough to permit basinby-basin studies of the GIS using 10 day averages of mascon data (Luthcke and others, 2006). Before mass loss can be estimated from the GRACE data, mascon solutions must be corrected for other geophysical signals. In this work, the 3 year trend as well as Earth and ocean tide and atmospheric mass signals have been removed. See Luthcke and others (2006) for details about the GRACE mascon data.

\section{RESULTS}

\subsection{Mean melt-season LST}

The mean LST map for the 7 year study period during the most active part of the melt season, May to mid-August, is

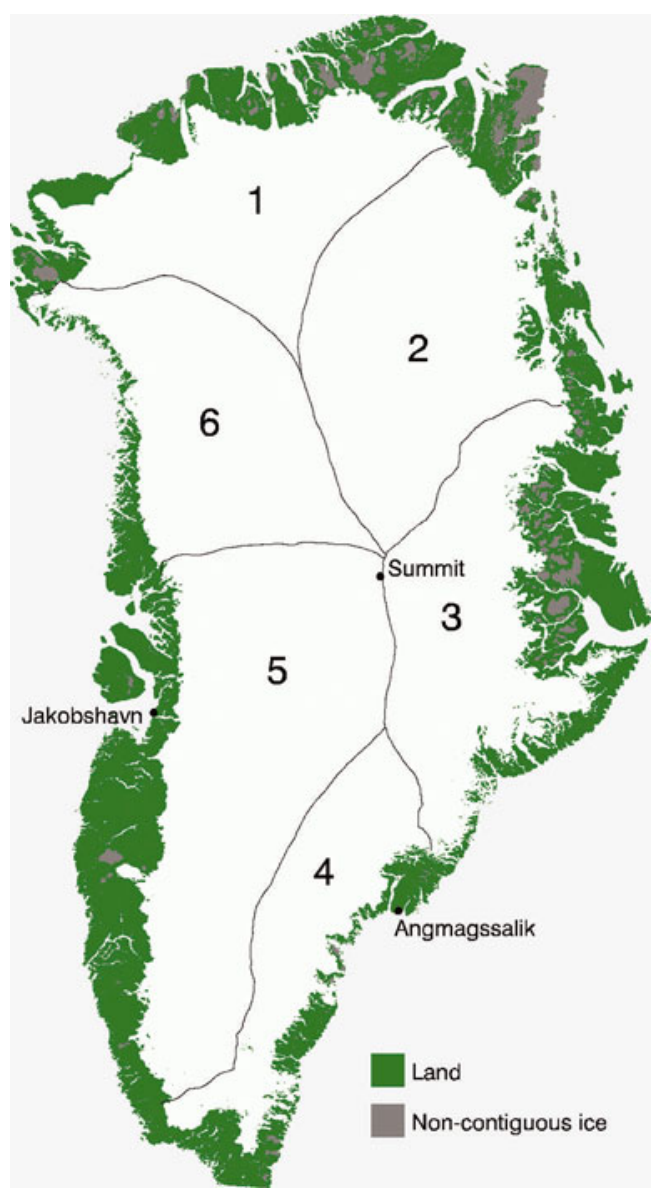

Fig. 1. Six major drainage basins of the GIS as modified from Zwally and others (2005). A land mask (shown in green) is included that was not part of the map of Zwally and others (2005). Ice caps and other glaciers that lie outside the margins of the GIS are shown in grey within the land mask. Only the major drainage basins delineated by Zwally and others (2005) are shown and not the sub-basins.

provided in Figure 2. The digital elevation model (DEM) of Bamber and others (2001) was overlaid, and the 2000 and $3000 \mathrm{~m}$ contours are shown $(62.2 \%$ of the ice sheet lies above $2000 \mathrm{~m}$ ). During the most active part of the melt season, the mean LST of the GIS for the study period is $-9.64 \pm 6.34^{\circ} \mathrm{C}$, varying from a low of $-11.03 \pm 6.59^{\circ} \mathrm{C}$ in 2000 , to a high of $-8.82 \pm 6.24^{\circ} \mathrm{C}$ in 2002 (Table 1). Note that in Figure 2 the margins of the southern part of the GIS (mean melt-season LST) are only a few degrees above $0^{\circ} \mathrm{C}$ (see also Box, 2002; Hanna and Cappelen, 2003). Thus those areas are particularly vulnerable to rapid mass loss with further increase in $T_{\mathrm{s}}$.

Mean LST during the most active part of the melt season was also calculated in each of the six major drainage basins. The years 2000 and 2001 experienced the lowest mean LST in all of the basins, followed by 2006. The years 2002 and 2005 experienced the highest mean LST in most of the basins (Table 1). Fausto and others (2007) noted a lot of variation in melting of the GIS between years, and particularly strong melting in 2002, 2003 and 2005. Our data show a trend toward higher mean melt-season LST in each of the drainage basins during the study period; it is strongest in basins 1, 2 and 6, the northern basins, with basins 1 and 2 having the most pronounced positive slopes $\left(0.274^{\circ} \mathrm{Ca}^{-1}\right.$ and $0.311^{\circ} \mathrm{Ca}^{-1}$, respectively) (Fig. 3), though the trends are 


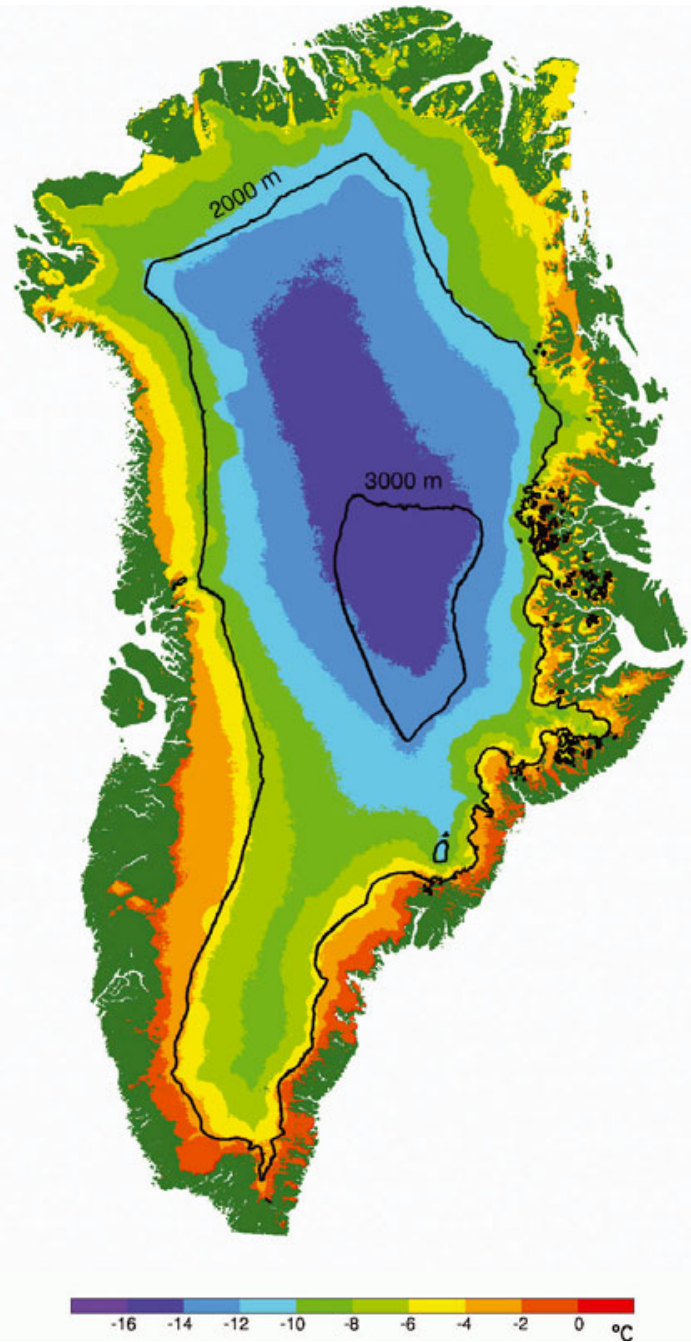

Fig. 2. Map showing mean LST of the GIS for the most active part of the melt season (days 121-225) during the study period (2000-06) as determined from MODIS LST data products (Wan and others, 2002). The 2000 and $3000 \mathrm{~m}$ contours from the DEM of Bamber and others (2001) are shown. A land mask is shown in green.

not statistically significant. Basin 4 has the highest mean LST and the least interannual variability in mean LST (lowest standard deviation) of all the basins because of the preponderance of pixels at $0^{\circ} \mathrm{C}$ compared with the other basins where the range in LST is relatively greater. This is not surprising, because drainage basin 4 is a relatively small basin and has the most marine exposure.

\subsection{Mean annual and seasonal LST}

We calculated the mean annual LST in two different ways. First, we took the average of all the LSTs of each pixel from 1 January 2001 to 31 December 2006, giving equal weight to each LST value (Fig. 4a). Then we averaged all the LSTs available for each month, determined a monthly mean LST, and from the monthly data we calculated a mean annual LST (Fig. 4b). We then compared our maps with a map of mean annual $T_{\mathrm{s}}$ derived by Steffen and Box (2001) from modeling and analysis of AWS data, and a map of mean annual temperature derived using the Polar MM5 model by Cassano and others (2001).

There is a warm bias to the mean annual LST map shown in Figure 4a. This occurs mainly because of missing days in the winter months due to cloud masking problems (see discussion in section 5). Compared with the maps of mean annual $T_{\mathrm{s}}$ of Steffen and Box (2001) and Cassano and others (2001), our MODIS-derived mean annual LSTs are up to $\sim 10^{\circ} \mathrm{C}$ higher at the highest elevations, when we give equal weight to each LST in calculating the mean LST (Fig. 4a). However, if we calculate mean annual LST by first calculating monthly averages, as shown in Figure $4 b$, the results are much closer to those of Steffen and Box (2001) and Cassano and others (2001), with temperatures at the highest elevations being up to $\sim 5^{\circ} \mathrm{C}$ higher. Both LST maps in Figure 4 show closer agreement with the maps of Steffen and Box (2001) and Cassano and others (2001) at the lowest elevations of the ice sheet. It is clear that the accuracy of the LST-derived maps is reduced because of the inability to measure LST through cloud cover, especially during the winter; however, that may not fully explain the higher LSTs in our study. The $T_{\mathrm{s}}$ has increased since the maps of Steffen and Box (2001) and Cassano and others (2001) were produced (see Steffen and others, 2005; Comiso, 2006b; and results herein), and it is therefore difficult to say how closely the maps 'should' match, especially at the higher elevations where enhanced warming has been measured using the LST data.

When all pixel values were given equal weight to calculate the mean annual LST (Table 2), 2001 experienced the lowest mean annual LST. The mean annual LSTs for the years studied show a more pronounced trend toward higher temperatures than do the LSTs from the active-melt period (Fig. 5). The most pronounced positive slopes characterize the northern basins (basin 1: $m=0.377^{\circ} \mathrm{Ca}^{-1}$; basin 2: $m=0.446^{\circ} \mathrm{Ca}^{-1}$; basin $\left.6: \mathrm{m}=0.383^{\circ} \mathrm{Ca}^{-1}\right)$, and the least positive characterize basins $4\left(m=0.004^{\circ} \mathrm{Ca}^{-1}\right)$ and $5(m=$ $0.084^{\circ} \mathrm{Ca}^{-1}$ ) as was also noted for the most active part of the

Table 1. Mean and standard deviation LSTs in ${ }^{\circ} \mathrm{C}$ of the six major drainage basins of the GIS for the most active part of the melt seasons, May to mid-August, 2000-06. The mean and standard deviation for the entire ice sheet (All) are also given

\begin{tabular}{|c|c|c|c|c|c|c|c|c|}
\hline Basin & 2000 & 2001 & 2002 & 2003 & 2004 & 2005 & 2006 & All years \\
\hline 1 & $-11.68 \pm 6.56$ & $-12.07 \pm 6.69$ & $-8.97 \pm 6.19$ & $-9.33 \pm 6.44$ & $-10.03 \pm 5.37$ & $-8.77 \pm 6.31$ & $-10.97 \pm 5.42$ & $-10.13 \pm 6.24$ \\
\hline 3 & $-10.70 \pm 6.23$ & $-10.48 \pm 5.98$ & $-8.74 \pm 6.14$ & $-9.24 \pm 5.94$ & $-9.20 \pm 6.09$ & $-8.91 \pm 6.16$ & $-9.72 \pm 5.64$ & $-9.55 \pm 6.07$ \\
\hline 4 & $-6.77 \pm 5.31$ & $-6.50 \pm 5.18$ & $-6.09 \pm 5.04$ & $-5.91 \pm 5.07$ & $-5.88 \pm 5.48$ & $-5.96 \pm 5.49$ & $-6.19 \pm 5.14$ & $-6.18 \pm 5.26$ \\
\hline 5 & $-9.64 \pm 6.16$ & $-8.64 \pm 6.15$ & $-7.93 \pm 5.63$ & $-7.67 \pm 6.03$ & $-7.88 \pm 6.14$ & $-7.87 \pm 5.99$ & $-8.62 \pm 5.81$ & $-8.29 \pm 6.02$ \\
\hline All & $-11.03 \pm 6.59$ & $-10.62 \pm 6.56$ & $-8.82 \pm 6.24$ & $-9.08 \pm 6.33$ & $-9.42 \pm 6.16$ & $-8.83 \pm 6.31$ & $-10.03 \pm 5.87$ & $-9.64 \pm 6.34$ \\
\hline
\end{tabular}



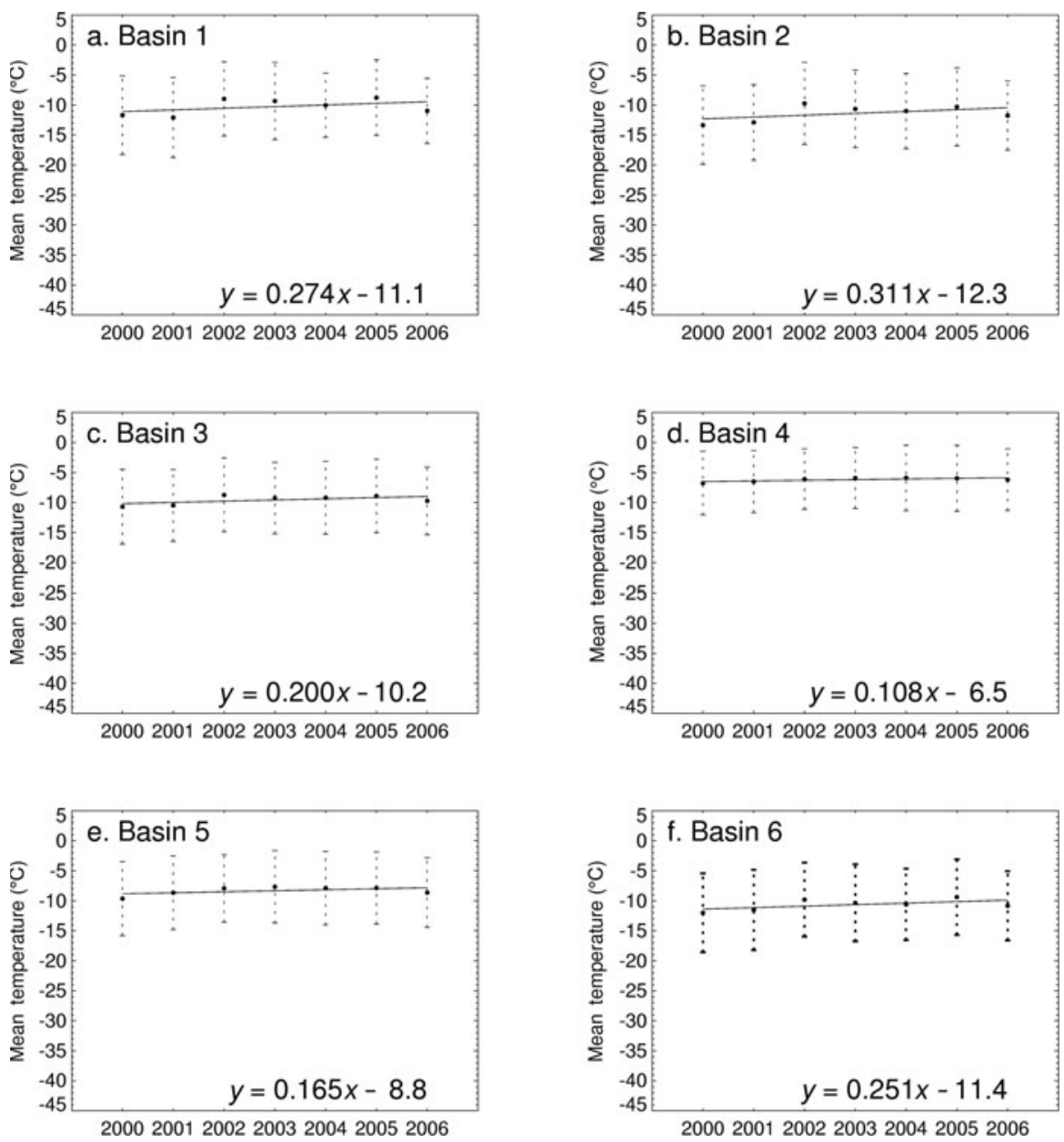

Fig. 3. Plots showing mean LST in each of six major drainage basins of the GIS for the most active part of the melt season (days 121-225) of each year from 2000 to 2006, as determined from MODIS LST data products, MOD11A1 (Wan and others, 2002).

melt season. However, in part due to the brevity of the record (6 years), none of these trends is statistically significant.

During the 6 year period from January 2001 to December 2006 , there is an overall increase in mean LST of the entire ice sheet of $\sim 0.27^{\circ} \mathrm{Ca}^{-1}$, with the higher-elevation areas $(>2000 \mathrm{~m})$ contributing more toward the observed increased mean annual temperatures (Fig. 6).

Seasonal plots were also produced using each pixel to develop a mean seasonal LST for each year from 2000 to 2006 (Fig. 7). The winter of 2000 could not be used due to the lack of MODIS data for January and most of February 2000. The increase in LST is greatest during the winter, where the slope $\left(m=0.890^{\circ} \mathrm{Ca}^{-1}\right)$ is the highest of the four seasons, and the mean LSTs are more variable than they are in other seasons.

\subsection{Melt-season timing, duration and frequency of melt}

Melt-season length was studied in each of the six major drainage basins (Fig. 8). Most of the basins (1, 2, 4 and 5) show a slightly longer melt season over the course of the study period, and a later start and end of the melt season (see positive slopes in basins 1, 2 and 6, and a later start only in basin 3). However, basins 4 and 5, in the southern half of the GIS, each show a pronounced trend toward an earlier start and end of the melt season, with the more pronounced trend being toward an earlier start of the melt season in both basins 4 and 5 by up to $\sim 18$ and 22 days, respectively. It is the earlier start of the melt season that is the main factor causing an overall longer melt season during the study period in these basins. The trends shown in Figure 8 are not statistically significant, and are likely to be quite different as more years are added to these plots.

The frequency of melt, especially in the southern half of the GIS (see basins 4 and 5), increases beginning in 2002, especially for very short-term melt of 1-2 days in duration (Fig. 9). The lowest frequency of melt is observed in 2000, and this is consistent with the mean melt-season LST of the GIS being the lowest that year (Table 1).

The number of years with a melt season (at least 2 days of consecutive melt to begin and end the melt season) is shown in Figure 10. Comparing Figures 9 and 10, note that large areas of the northeastern (in 2002) and southern GIS (in 2003, 2004, 2005 and 2006) show short-term melt of generally $\leq 7$ days (see purple color on map), the importance of which is discussed in section 6 .

\subsection{Mass change}

We now focus on melt on the GIS at elevations $<2000 \mathrm{~m}$ using MODIS LST and mascon solution data from GRACE. Shortly after surface melt begins (defined herein as $1 \%$ of the ice sheet experiencing melt) rapid mass loss occurs in 2004 and 2005, the only years during which reprocessed GRACE mascon data are complete (Fig. 11). Initiation of mass loss appears to be very sensitive to small amounts of surface melt. We calculated a melt index (MI) anytime the percentage of 

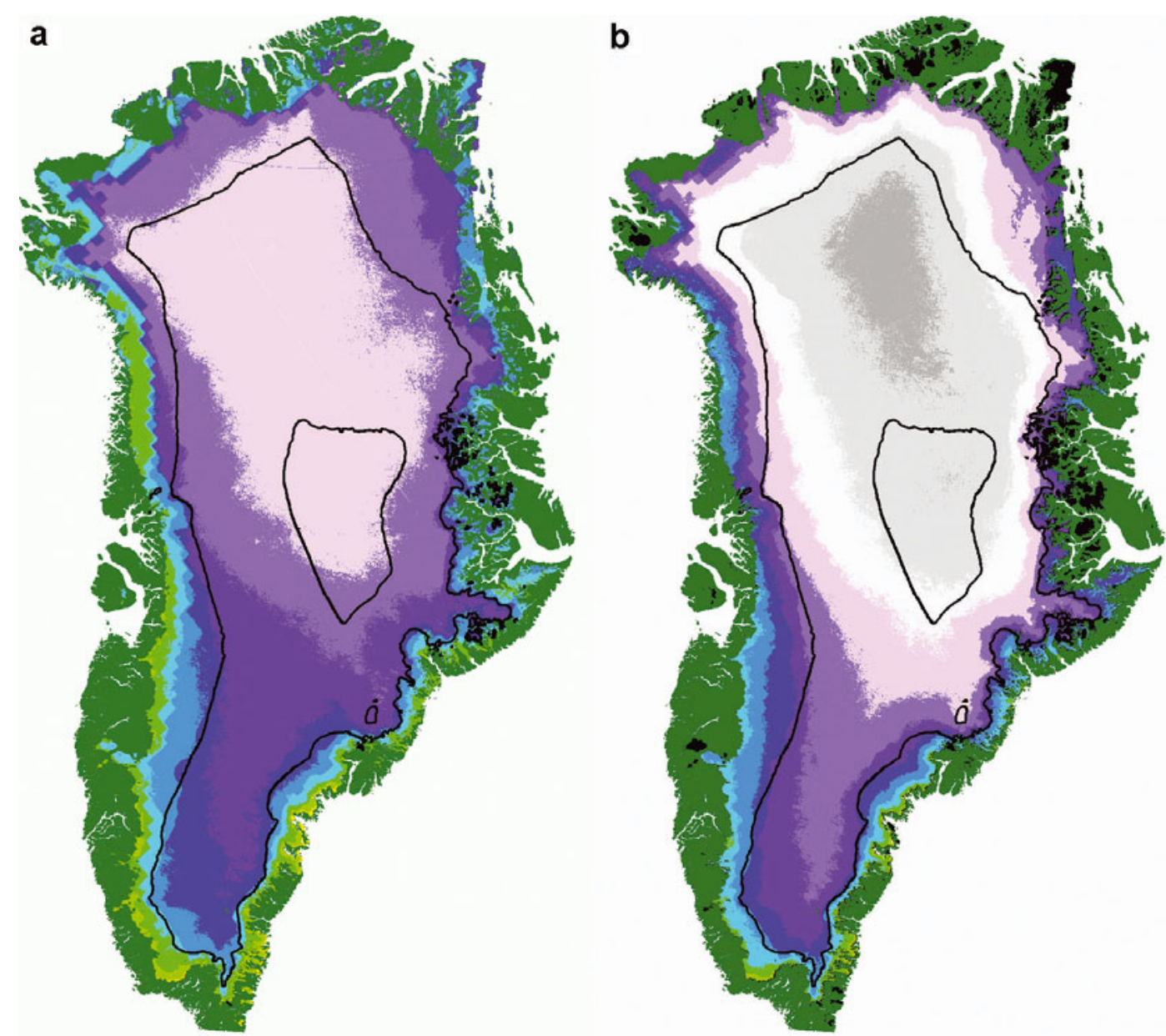

$<$\begin{tabular}{llllllllllllllll}
\hline & -26 & -24 & -22 & -20 & -18 & -16 & -14 & -12 & -10 & -8 & -6 & -4 & -2 & -0 & 0 \\
\hline
\end{tabular}

Fig. 4. (a) Map showing mean annual LST of the GIS calculated using a technique that gives equal weight to all pixels in the calculation of the mean annual LST. (b) Map showing mean annual LST calculated using monthly average LST to calculate mean annual LST. The 2000 and $3000 \mathrm{~m}$ contour lines from the DEM of Bamber and others (2001) are shown. A land mask is shown in green.

clear-sky pixels for the entire ice sheet experiencing melt was $1 \%$ or greater according to the LST maps. The MI is the sum of the daily percentages of melt over a specified period of time. In 2004 and 2005 melt seasons, the $\mathrm{MI}$ is 1046.50 and 1115.20, respectively, and there is a corresponding greater mass loss in 2005 (443.7 Gt) compared with 2004 (321.1 Gt). There was a $<15$ day delay from melt onset $(\mathrm{MI} \geq 1)$ to initiation of mass loss in both 2004 and 2005. There is a longer delay from cessation of melt to the beginning of sustained mass gain (<30 days) for 2003, 2004 and 2005. This is reasonable because there can be a significant amount of liquid water in the upper layers of snow and firn of the ice sheet even after the ice-sheet surface refreezes. Since the mascon data represent $\sim 10$ day averages, the exact number of days of delay from onset of melt to initiation of mass loss cannot be calculated.

The annual contribution of meltwater from the GIS to changes in eustatic sea level can be estimated by dividing the

Table 2. Mean and standard deviation LSTs in ${ }^{\circ} \mathrm{C}$ of the six major drainage basins of the GIS for January-December 2001-06. The mean and standard deviation for the entire ice sheet (AII) are also given. Because the month of January and most of February 2000 were unavailable (the MODIS sensor first began acquiring data on 24 February 2000), the year 2000 is not included

\begin{tabular}{|c|c|c|c|c|c|c|c|}
\hline Basin & 2001 & 2002 & 2003 & 2004 & 2005 & 2006 & All years \\
\hline 1 & $-21.03 \pm 11.28$ & $-18.44 \pm 11.75$ & $-19.84 \pm 12.09$ & $-18.55 \pm 11.05$ & $-18.28 \pm 11.14$ & $-18.75 \pm 10.28$ & $-19.13 \pm 11.33$ \\
\hline 2 & $-21.35 \pm 10.74$ & $-18.97 \pm 11.73$ & $-20.09 \pm 11.68$ & $-18.80 \pm 10.84$ & $-18.52 \pm 10.58$ & $-18.75 \pm 10.24$ & $-19.40 \pm 11.05$ \\
\hline 3 & $-18.10 \pm 10.00$ & $-17.06 \pm 10.88$ & $-17.46 \pm 11.23$ & $-17.34 \pm 10.62$ & $-16.66 \pm 9.97$ & $-16.83 \pm 9.91$ & $-17.23 \pm 10.46$ \\
\hline 4 & $-14.11 \pm 9.67$ & $-14.32 \pm 10.02$ & $-13.70 \pm 10.47$ & $-14.46 \pm 10.39$ & $-14.18 \pm 9.71$ & $-14.01 \pm 9.85$ & $-14.12 \pm 10.03$ \\
\hline 5 & $-16.36 \pm 10.18$ & $-15.87 \pm 10.43$ & $-15.86 \pm 10.88$ & $-16.00 \pm 10.65$ & $-15.56 \pm 10.01$ & $-15.93 \pm 10.07$ & $-15.93 \pm 10.39$ \\
\hline All & $-18.72 \pm 10.79$ & $-17.42 \pm 11.17$ & $-18.07 \pm 11.54$ & $-17.45 \pm 10.83$ & $-16.96 \pm 10.47$ & $-17.20 \pm 10.22$ & $-17.63 \pm 10.87$ \\
\hline
\end{tabular}



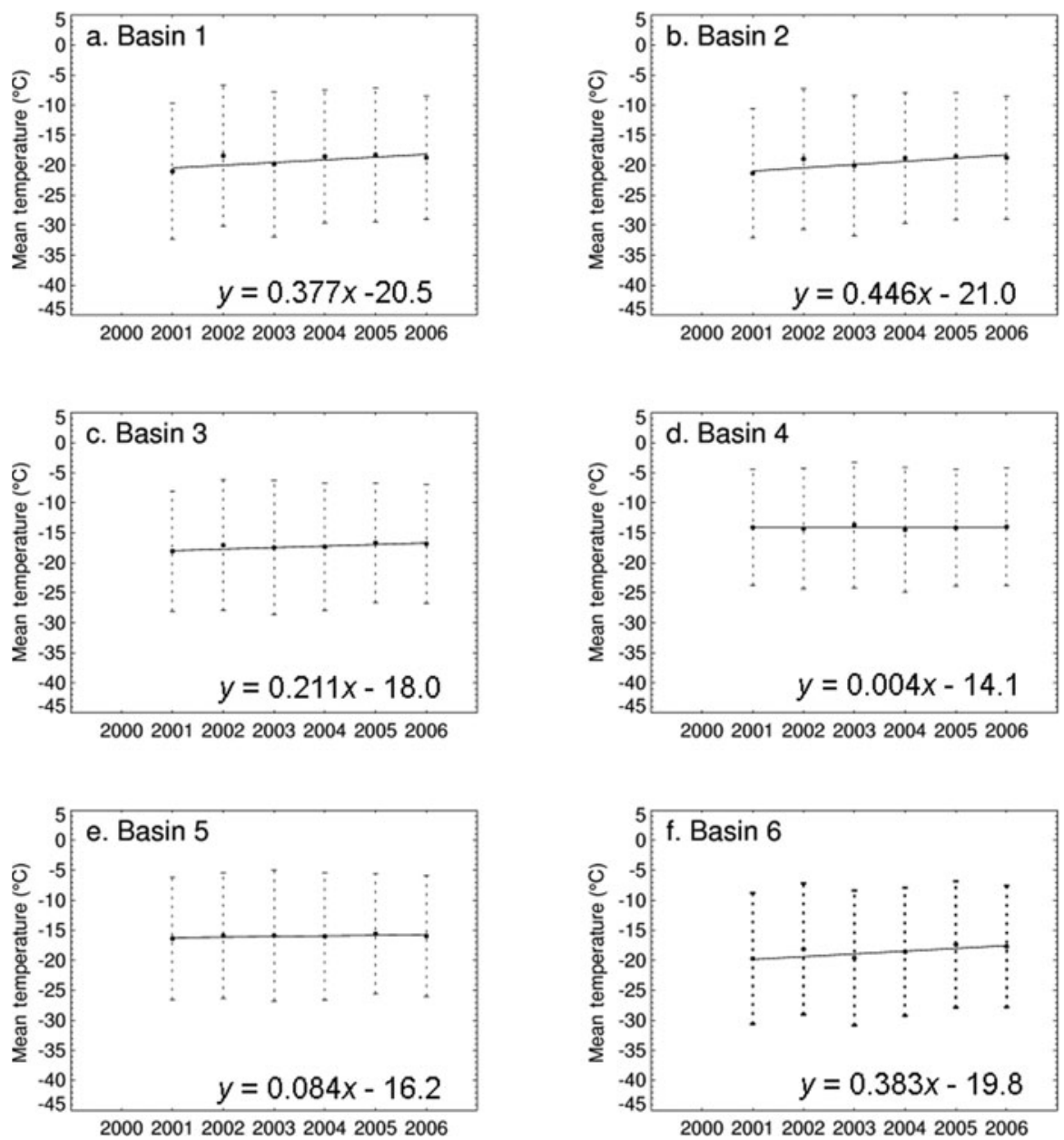

Fig. 5. Plots showing mean annual LST in each of six major drainage basins for each year from 2001 to 2006, as determined from MODIS LST data products, MOD11A1 (Wan and others, 2002). The year 2000 is excluded because MODIS data from January and most of February are not available.

annual mass loss (in Gt) by 400, the volume of ice (in $\mathrm{km}^{3}$ ), needed to raise (or lower) global sea level by $1 \mathrm{~mm}$ (Williams and Hall, 1993). Thus for the 2004 and 2005 melt seasons discussed above, the total contribution to sea-level rise was $1.9 \mathrm{~mm}$, according to the mascon data for those parts of the ice $<2000 \mathrm{~m}$ a.s.l. This was partly compensated for by mass gains during the accumulation seasons at all elevations.

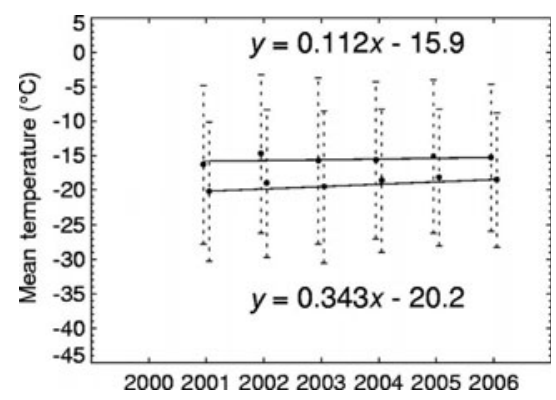

Fig. 6. Mean annual LSTs for the entire GIS, showing mean annual LST over the study period at two different elevation ranges $(\leq 2000 \mathrm{~m}$ and $>2000 \mathrm{~m}$ ), as determined from the DEM of Bamber and others (2001). The lower solid line represents the higher elevation range (lower LSTs), and the upper solid line represents the lower elevation range (higher LSTs). The dotted lines are the error bars.

\subsection{Northern Annular Mode (NAM) forcing}

Is there a relationship between the NAM and the observation of wintertime temperature increase in the northern basins of the GIS during the MODIS era? The NAM has shown a trend toward a high index polarity during the last few decades, especially during the Northern Hemisphere winter, with a

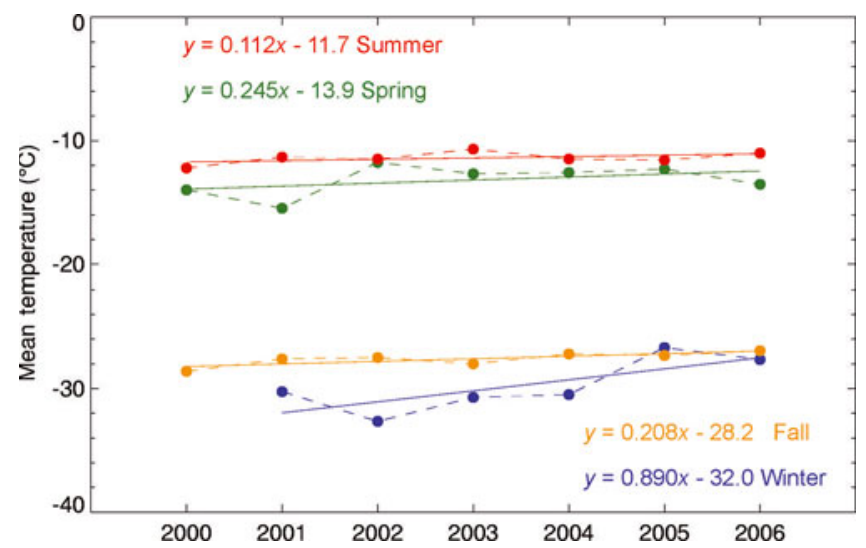

Fig. 7. Mean seasonal LSTs for the entire GIS. Note the greater increase in mean winter LST over the course of the study period compared with the other seasons. 

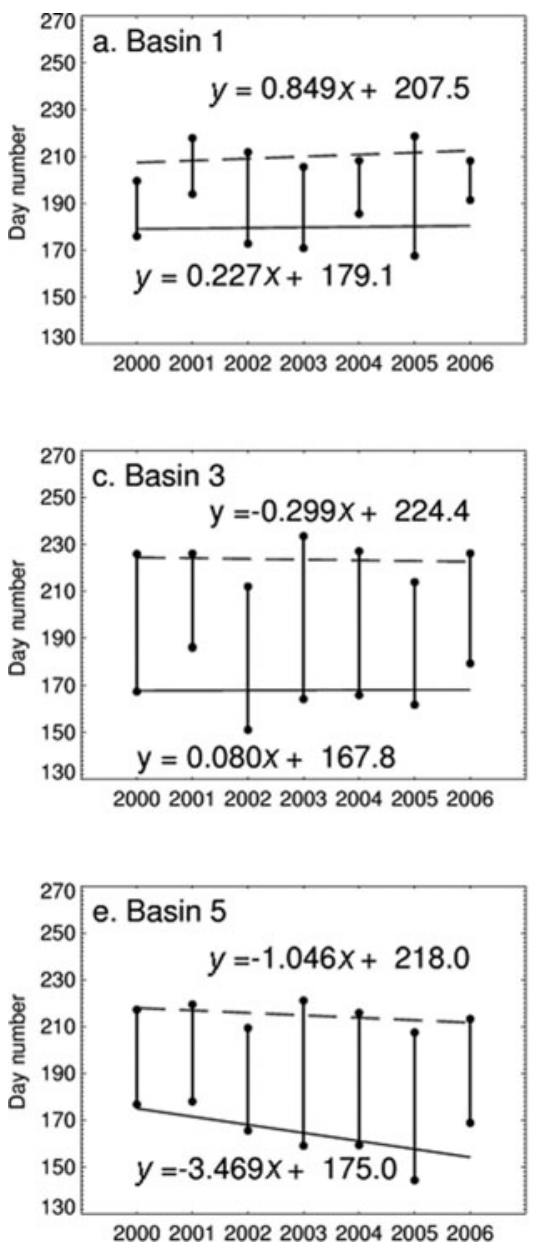
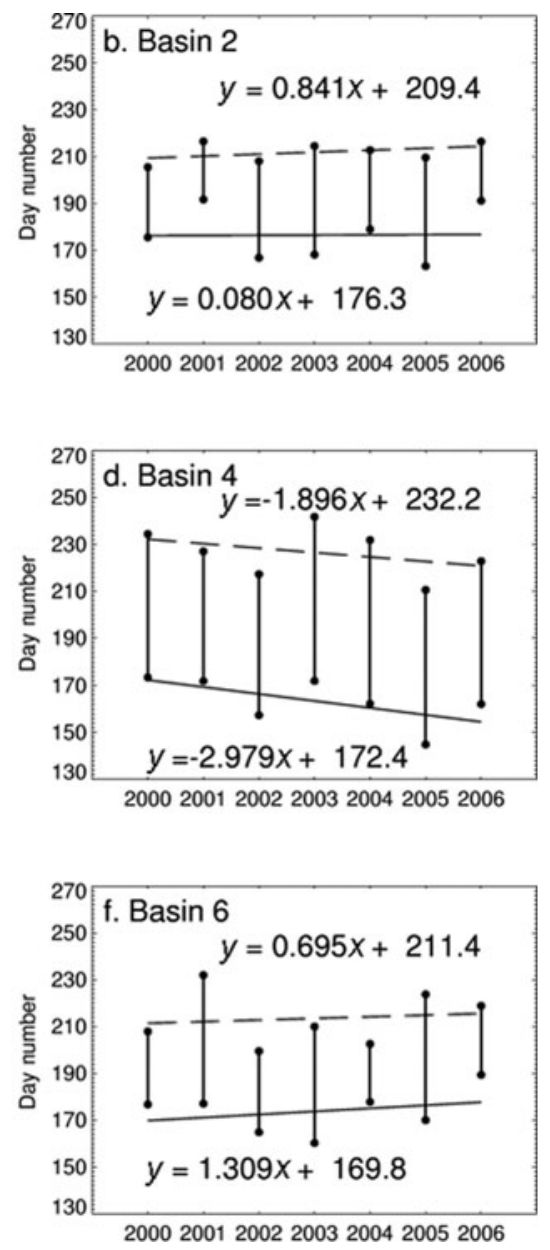

Fig. 8. Timing and duration of melt seasons, 2000-06, in each of the six major drainage basins of the GIS determined from MODIS, LST data products, MOD11A1, developed by Wan and others (2002). The 'melt season' is based on two consecutive days of melt to begin and end the melt season; see text for further explanation. The formula for the slope of the trend line for the start of the melt season (see solid line) is shown in the bottom in each panel, and the formula for the slope of the trend line for the end of the melt season (see dashed line) is shown at the top. Duration of the melt season is shown with the vertical bars; least-squares-fit lines are fitted to the points.

relaxation in the past decade (Cohen and Barlow, 2005). Though a relaxation, or weakening, of the NAM has been associated with warmer temperatures on the GIS, there are simply not enough years in the data record to attribute the recent relaxation in the NAM index to the observed 6-7 year increase in the surface temperatures of the GIS reported herein. It is also interesting to note that climate models have failed to simulate a consistent trend in the NAM in response to increasing greenhouse gases (IPCC, 2007; D.W.J. Thompson, 2007, http://atmos.colostate.edu/ao/introduction.html).

\section{LIMITATIONS AND UNCERTAINTIES}

Although the measurement accuracy of MOD11A1 is $\pm 2{ }^{\circ} \mathrm{C}$ over ice-and-snow surfaces in the absence of cloud (Wan and others, 2002; Hall and others, 2006), the major limitation in the derived LST occurs when thin clouds are not detected by the cloud mask that is an input to the MOD11A1 algorithm. Under such conditions an LST is calculated for the pixel, but the derived value may not be accurate. Depending on the type and altitude of the thin cloud, and the $T_{\mathrm{s}}$ of the ice/snow, the derived LST may be higher or lower than the actual $T_{\mathrm{s}}$.

Over ice, it is more difficult to discriminate clear sky from clouds with MODIS data during the polar night, in part due to a small, or lack of, thermal contrast between the cloud and the ice/snow surface, and temperature inversions that may occur over the ice sheet. Thus the number of total pixels available to compile the LST maps varies by season, with a much lower number of pixels available for use during the winter compared with the summer (Table 3). Therefore, the mean LST values do not represent actual mean values of $T_{\mathrm{s}}$ which is why they are called 'clear-sky' surface temperatures. An average of only 26.0 days is available to retrieve LST during the winter seasons (January-March) during the 6 year study period, while almost 2.5 times as many days (an average of 64.7 days) is available during the summer seasons (June-August) (Table 3).

To calculate mean annual LST, all MODIS LST values from the ice sheet were used (that is, all cloud-free pixels) that passed the quality-assurance tests in the algorithm. A total of $19109051 \mathrm{~km}$ pixels covers the GIS, but in any given day, fewer than that number of pixels is available to develop an LST map, due to cloud cover. Thus, calculation of mean LST results in using different numbers of total pixels for different areas in different years. (Note: the area of the inland ice (GIS) was estimated at $1736095 \mathrm{~km}^{2}$ by Weidick (1995); our measurement of the ice-sheet area is within $10 \%$ of that value. The difference is caused by the inclusion of nunataks and other ice-free areas and possible differences in the land masks used.) 

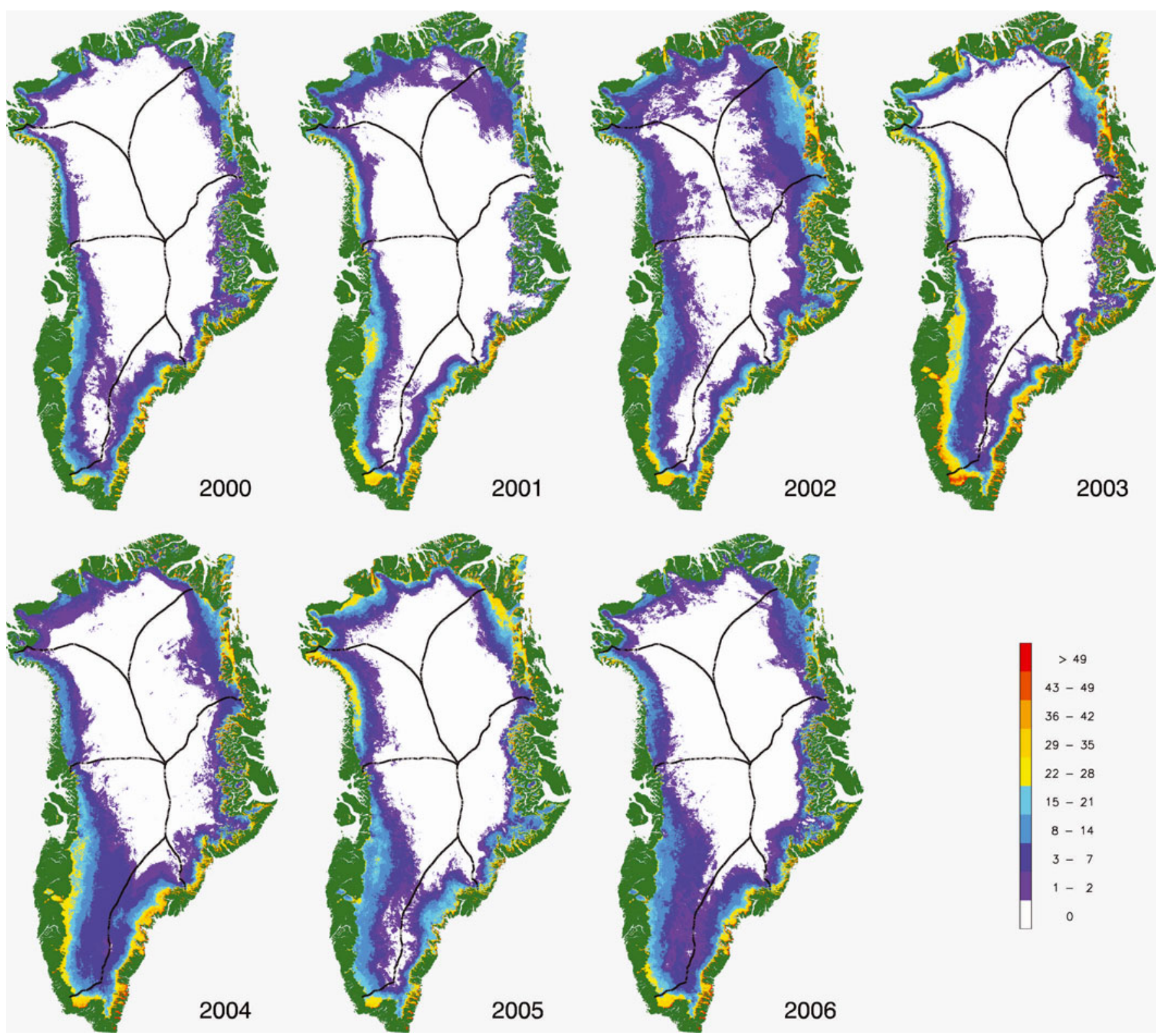

Fig. 9. Number of days of melt on the GIS from 29 February/1 March to 29/30 November (days 60-334) of each year from 2000 to 2006 , based on MODIS land-surface temperature data products, MOD11A1 (Wan and others, 2002). Black lines delineate the six major drainage basins. A land mask is shown in green.

A few spurious pixels $\left(>0^{\circ} \mathrm{C}\right)$ are found on the ice sheet, and for the purpose of the calculations of mean LST these pixel values were changed to $0^{\circ} \mathrm{C}$. For instance, for MarchNovember 2006, out of 285924066 total clear-sky pixels studied, only $0.02 \%$ were $>2{ }^{\circ} \mathrm{C}$. Incorrect cloud masking by the MODIS cloud mask is the most likely reason that a few pixels provide erroneous LSTs. Other possible but less likely reasons for these elevated LST values include the possibility that LST in a pixel that contains many melt ponds could exceed $0^{\circ} \mathrm{C}$ sometime during the melt season, and, because of mixed-pixel effects (ice and melt ponds), could cause a pixel value to exceed the freezing point of water. If the water temperature is $>0^{\circ} \mathrm{C}$ and the ice temperature is $0^{\circ} \mathrm{C}$, then a mixed pixel could have a temperature $>0^{\circ} \mathrm{C}$.

Compared with earlier work by Hall and others (2006), who used $5 \mathrm{~km}$ MODIS 8 day composite LST data, the daily $1 \mathrm{~km}$ resolution MODIS maps used in the present study provide improved results. There is a difference in the way that the LST is calculated to derive the 5 and $1 \mathrm{~km} \mathrm{LST}$ products. A split-window algorithm is used to generate the $1 \mathrm{~km}$ maps, and a day-night difference algorithm is used to generate the $5 \mathrm{~km}$ maps (Wan and others, 2002). Thus both the difference in algorithms and the difference in temporal and spatial resolution will contribute to different LSTs over the same general area of the ice sheet. For instance, in the most active part of the melt season, mean LST values of the GIS are consistently lower, by $\sim 0.5-1.0^{\circ} \mathrm{C}$, using the higherresolution data. The lower LSTs reported herein using the $1 \mathrm{~km}$ daily data are more consistent with the published mean annual $T_{\mathrm{s}}$ map of Steffen and Box (2001) and Cassano and others (2001).

MODIS Collection 5 (C5) data production began in January 2007 and should be completed by September 2008. The primary difference between Collections 4 and 5, relative to this work, is improved cloud masking in Collection 5, especially during night-time conditions, which results in a 


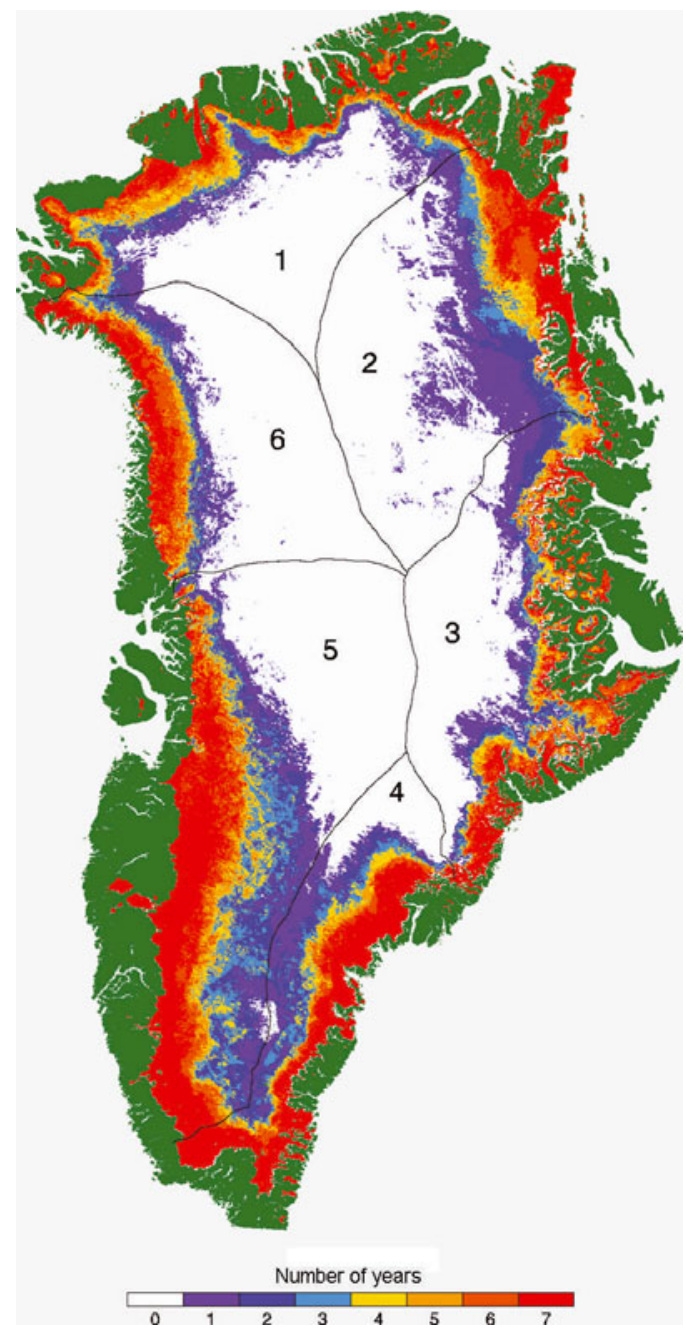

Fig. 10. Number of years with a melt season on the GIS as discussed in the text. Black lines delineate the six major drainage basins. A land mask is shown in green.

more accurate and less conservative cloud mask. Therefore more clear-sky pixels will be available to calculate LST, and this is expected to improve the accuracy in producing maps of LST, especially in the winter months.

\section{DISCUSSION AND CONCLUSIONS}

We have calculated least-squares-fit trend lines for the LST data of the entire ice sheet, and in each of the major drainage basins (Figs 3-8). While none of the trends is statistically significant, in part due to the brevity of the record, they are consistent with trends seen using a variety of other observations. However each additional point (year) can quite easily change the 'trend' since there are so few years of data available. Furthermore, as noted earlier and also by Fausto and others (2007), the interannual variability in surface melt is quite high. Thus it will take many more years to develop a consistent picture of the GIS melt and LST patterns and to make a determination about external forcings and statistically significant trends.

\subsection{Melt-season, seasonal and mean annual LSTs}

Our results show relatively low mean LSTs in 2000, 2001 and 2006, and relatively high mean LSTs in 2002 and 2005 (Table 1), during the period of most active melt. These results
Table 3. Percentage of total possible LST observations (pixels) per season. Note the reduced percentage of observations in the winter and fall compared with spring and summer

\begin{tabular}{lcccc}
\hline Year & Winter & Spring & Summer & Fall \\
\hline 2000 & - & 62.45 & 53.64 & 37.99 \\
2001 & 25.15 & 50.37 & 66.91 & 42.17 \\
2002 & 15.90 & 59.74 & 66.70 & 49.05 \\
2003 & 30.95 & 65.52 & 66.84 & 46.41 \\
2004 & 29.45 & 67.89 & 68.47 & 36.57 \\
2005 & 26.49 & 64.75 & 63.54 & 37.59 \\
2006 & 28.01 & 61.66 & 66.61 & 36.10 \\
\hline
\end{tabular}

agree with those of Steffen and others (2006) who found enhanced melting in 2002 and 2005 using passive microwave data, and Fausto and others (2007) who found greater melt in 2002 and 2005 using MODIS data. When the mean annual LST (Fig. 4b) map is calculated by deriving monthly averages before calculating the mean annual LST, the values are closer to the published values of Steffen and Box (2001) and Cassano and others (2001), but still show higher LSTs, especially at the highest elevations of the ice sheet. Because of ice-sheet warming, especially in recent years at the higher elevations $(>2000 \mathrm{~m})$, it is expected that the mean annual LSTs (shown in Fig. 4) are higher than those reported by Steffen and Box (2001) and Cassano and others (2001).

Slopes of least-squares-fit lines of MODIS-derived LST vary at different elevations and in different drainage basins of the GIS during the study period. Each of the six major drainage basins of the GIS reacts differently because of its unique topographic and geographic position and relationship to internal and external forcings. Thus each has different mean LSTs and differences in melt-season length, duration and timing.

Data from land-based meteorological stations that are associated with drainage basin 4 show trends toward increasing air temperature. Temperature records at Angmagssalik station in southeastern Greenland $\left(65^{\circ} 40^{\prime} \mathrm{N}\right.$, $37^{\circ} 20^{\prime} \mathrm{W}$ ) show a $3^{\circ} \mathrm{C}$ increase in annual air temperature from approximately the early 1980s to the present (Rignot and Kanagaratnam, 2006). Across the Denmark Strait, about $700 \mathrm{~km}$ to the east of Angmagssalik, data from the meteorological station at Stykkishólmur, northwestern Iceland $\left(65^{\circ} 2^{\prime} \mathrm{N}, 22^{\circ} 40^{\prime} \mathrm{W}\right)$, show dramatically increased summer mean temperatures in recent years (Jónsson and Garðarsson, 2001; Hanna and others, 2004; personal communication from O. Sigurðsson, 2007), and increasing mean annual temperatures. The increased melt observed in basin 4 is consistent with the meteorological station data showing higher air temperatures in recent years.

Though not statistically significant, the increase we found in mean annual LST $\left(0.27^{\circ} \mathrm{Ca}^{-1}\right)$ represents a trend toward increasing $T_{\mathrm{s}}$ and is comparable to, though greater than, the rate of increase of mean $T_{\mathrm{s}}$ of the GIS from 1981 to 2005 given by Comiso $(2006 \mathrm{~b})\left(\sim 0.12^{\circ} \mathrm{Ca}^{-1}\right)$ of $T_{\mathrm{s}}$ based on monthly AVHRR data at $6.25 \mathrm{~km}$ resolution, and the $0.11^{\circ} \mathrm{Ca}^{-1}$ increase in temperature at the summit of the ice sheet found by Box (2002). The trend towards an increase in mean annual LST is driven by the LST increase at the higher elevations $(>2000 \mathrm{~m})$ as seen in Figure 6. Comiso (2006a) noted an increase in the rate of temperature increase in parts 


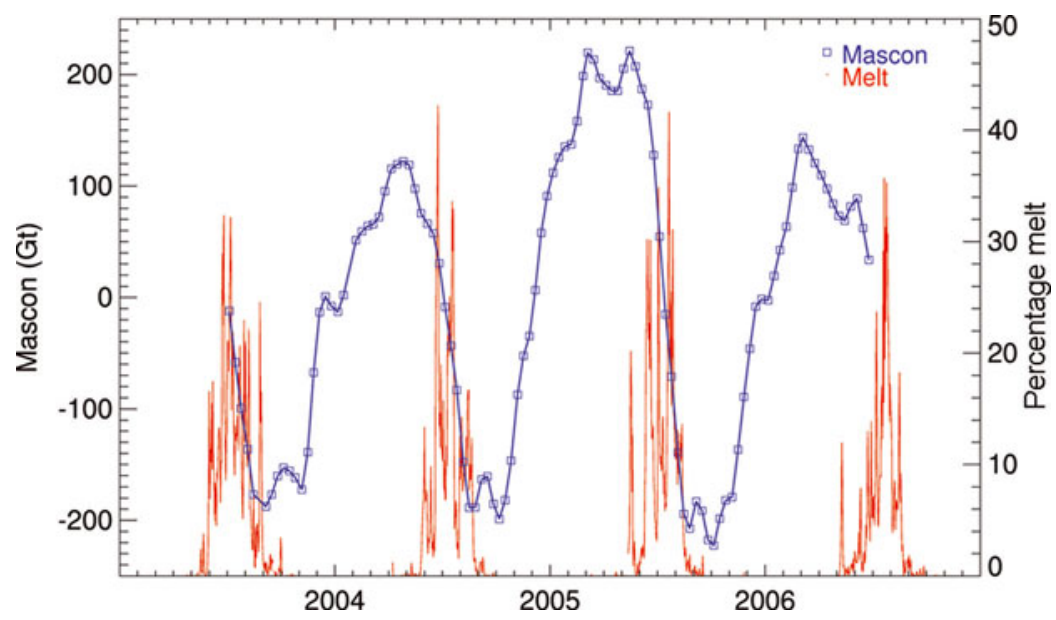

Fig. 11. MODIS-derived percentage of melt (see text for explanation) with GRACE-derived mass concentration (mascon) data, in Gt, for the entire Greenland ice sheet, for July 2003 to July 2006. The mascon plot is shown with the 3 year trend, as well as Earth and ocean tide and atmospheric mass signals removed.

of the Arctic in recent years, so the greater rate of temperature increase, compared with the results of Comiso (2006b) and Box (2002), is reasonable.

The observed temperature increases in the northern basins of the GIS (Figs 3 and 5) are driven by the enhanced warming during the winter seen in Figure 7; enhanced wintertime warming in the Arctic has also been discussed by others (Box, 2002; Steffen and others, 2005; Comiso, 2006a). Steffen and others (2006) report that winter air temperatures in the western GIS increased by as much as $0.5^{\circ} \mathrm{Ca}^{-1}$ during the past 15 years; our MODIS LST results show an increase in LST of $\sim 0.33^{\circ} \mathrm{Ca}^{-1}$ from 2001 to 2006 (Fig. 6). The LST increases are greater during the winter than during spring, summer and fall (Fig. 7), but are not statistically significant.

\subsection{Melt-season timing and duration}

Interannual differences in melt-season timing have changed quite rapidly in southeastern and southwestern Greenland, especially in drainage basins 4 and 5, during the last 7 years. The melt season began up to 18 and 22 days earlier in basins 4 and 5, respectively, from 2000 to 2006. However, most of the other basins experienced no notable change, or a later start of the melt season during the study period, except for basin 6 which showed a more pronounced later start (and end) of the melt season over the course of the study period. We also found trends toward an increase in the length of the melt season in most of the basins, and especially in basin 5 (Fig. 8). Basin 4 and the southern and western parts of basin 5 are especially vulnerable to rapid melt because the mean $T_{\mathrm{s}}$ is already near $0^{\circ} \mathrm{C}$ according to the maps of Steffen and Box (2001) and Cassano and others (2001), and our melt-season LST map (Fig. 2).

Basins 4 and 5 are also the basins with the highest mean LSTs, the greatest amount of melt during the most active part of the melt seasons, and where most of the accelerated outlet-glacier activity is occurring. Most of the increase in velocity of outlet glaciers (Joughin and others, 2004; Ekström and others, 2006; Rignot and Kanagaratnam, 2006) is occurring in basins 4 and 5 where a large volume of shortterm ( $\leq 7$ days) surface meltwater is produced (Figs 9 and 10). Especially notable is the observation by Ekström and others (2006) that out of the 136 seismic events that they studied (1993-2005), relating to increase in velocity of outlet glaciers, 93 (or $68 \%$ ) occurred in basin 4 in southeast Greenland.

\subsection{Relationship of surface melt to mass loss}

The sensitivity of the initiation of mass loss to surface melt is striking in the 2004 and 2005 melt seasons, with $<1 \%$ of icesheet melt needed to trigger mass loss. GRACE gravimetry data show general mass loss of the GIS since its 2003 launch (Luthcke and others, 2006; Velicogna and Wahr, 2006). When surface melt begins, mass loss is initiated within $<15$ days thereafter, as seen in Figure 11. The dramatic influence of the surface melt on mass loss has been demonstrated, but not previously on such a large scale over the entire ice sheet.

There are two possible mechanisms for surface melt contributing to rapid mass loss. One possibility is that evaporation may increase substantially when surface melt begins, especially in windy parts of the ice sheet. Another possibility, as discussed by Zwally and others (2002), is that surface melt can flow rapidly to the base of the ice sheet, causing enhanced lubrication at the ice-rock interface, and thus cause faster movement of outlet glaciers and accelerated mass loss. This is thought (Rignot and Kanagaratnam, 2006; Howat and others, 2007) to be responsible for rapid acceleration of outlet glaciers and thus increased mass loss.

Gravimetry mascon data from the GRACE satellite are limited in length, but as more years of MODIS and GRACE data become available, it will be interesting to see if the relationship between the timing of surface melt and mass loss holds. Similar studies at the basin scale will also be conducted in the future.

\subsection{Importance of surface melt}

Even short-term melt ( $\leq 7$ days) observed over large parts of the southern part of the ice sheet from 2003 to 2006 (Fig. 9) is important for the temperature regime of the GIS. Echelmeyer and others (1992) show that latent-heat release upon refreezing just above the equilibrium line is a major source of warming in snow and firn. Surface meltwater may infiltrate $3 \mathrm{~m}$ or more into the cold firn where it may refreeze and thus not run off, causing densification and compaction of the firn (Echelmeyer and others, 1992; 
Benson, 1996). This can lower the surface elevation, whereas lower temperatures raise the surface elevation according to Zwally and others (2005) who require surface temperature as a parameter in the firn-compaction model. Accurate surface temperatures, derived from satellites, are necessary to provide accurate surface-elevation measurements using satellite-laser altimetry, such as topographic profiles produced by the Ice, Cloud and land Elevation Satellite (ICESat).

\subsection{External forcings}

Though the NAM has weakened (positive and negative index values are generally less pronounced) in recent years compared with the late 1990s and early 2000s, there are not enough years of data to determine a statistically significant NAM trend that would explain the pattern of LST increase that we have observed (enhanced LST increases in the northern basins during the winter).

\subsection{Conclusion}

LST data provide melt-season extent, length, timing and duration. In combination with GRACE gravimetry data, the influence of surface melt on the initiation and cessation of mass loss may be assessed. This key relationship between surface melt and initiation of mass loss points strongly to rapid movement of surface water to the base of the ice sheet. It also highlights the extreme vulnerability of the ice sheet to increasing air temperatures, especially in the southern half of the ice sheet where melt-season temperatures are only a few degrees from $0^{\circ} \mathrm{C}$. If air temperatures continue to rise over Greenland, increased surface melt will play a large role in ice-sheet mass loss.

\section{ACKNOWLEDGEMENTS}

We thank J. Zwally for providing us with the Greenland ice sheet drainage basin data; K. Steffen for providing us with the Steffen and Box (2001) surface-temperature map; J. Bamber for providing us with the DEM of Greenland; and D. Thompson for discussions about the NAM. We also thank O. Sigurðsson for data from the Stykkishólmur meteorological station, and an associated discussion. We thank J. Comiso, T. Scambos and two anonymous reviewers for their reviews. This work was supported by NASA's Cryospheric Sciences Program.

\section{REFERENCES}

Abdalati, W. and K. Steffen. 2001. Greenland ice sheet melt extent: 1979-1999. J. Geophys. Res., 106(D24), 33,983-33,988.

Ackerman, S.A., K.I. Strabala, P.W.P. Menzel, R.A. Frey, C.C. Moeller and L.E. Gumley. 1998. Discriminating clear sky from clouds with MODIS. J. Geophys. Res., 103(D24), 32,141-32,157.

Appenzeller, C., J. Schwander, S. Sommer and T.F. Stocker. 1998. The North Atlantic Oscillation and its imprint on precipitation and ice accumulation in Greenland. Geophys. Res. Lett., 25(11), 1939-1942.

Arctic Climate Impact Assessment (ACIA). 2005. Arctic climate impact assessment: scientific report. Cambridge etc., Cambridge University Press.

Bamber, J.L., S. Ekhölm and W.B. Krabill. 2001. A new, highresolution digital elevation model of Greenland fully validated with airborne laser altimeter data. J. Geophys. Res., 106(B4), 6733-6746.
Benson, C. S. 1996. Stratigraphic studies in the snow and firn of the Greenland ice sheet. SIPRE Res.Rep. 70.

Bindoff, N.L. and 12 others. 2007. Observations: oceanic climate change and sea level. In Solomon, S. and 7 others, eds. Climate change 2007: the physical science basis. Contribution of Working Group I to the Fourth Assessment Report of the Intergovernmental Panel on Climate Change. Cambridge, etc., Cambridge University Press, 384-432.

Box, J.E. 2002. Survey of Greenland instrumental temperature records: 1873-2001. Int. J. Climatol., 22(15), 1829-1847.

Box, J.E. and 8 others. 2006. Greenland ice sheet surface mass balance variability (1988-2004) from calibrated polar MM5 output. J. Climate, 19(12), 2783-2800.

Braithwaite, R.J. and O.B. Olesen. 1993. Seasonal variation of ice ablation at the margin of the Greenland ice sheet and its sensitivity to climate change, Qamanârssûp sermia, West Greenland. J. Glaciol., 39(132), 267-274.

Cassano, J.J., J.E. Box, D.H. Bromwich, L. Li and K. Steffen. 2001. Evaluation of Polar MM5 simulations of Greenland's atmospheric circulation. J. Geophys. Res., 106(D24), 33,867-33,889.

Chen, J.L., C.R. Wilson and B.D. Tapley. 2006. Satellite gravity measurements confirm accelerated melting of Greenland ice sheet. Science, 313(5795), 1958-1960.

Cohen, J. and M. Barlow. 2005. The NAO, the AO, and global warming: how closely related? J. Climate, 18(21), 4498-4513.

Comiso, J.C. 2006a. Abrupt decline in the Arctic winter sea ice cover. Geophys. Res. Lett., 33(18), L18504. (10.1029/2006GL027341.)

Comiso, J.C. 2006b. Arctic warming signals from satellite observations. Weather, 61(3), 70-76.

Comiso, J.C., J. Yang, S. Honjo and R.A. Krishfield. 2003. Detection of change in the Arctic using satellite and in situ data. J. Geophys. Res., 108(C12), 3384. (10.1029/2002JC001347.)

Echelmeyer, K., W.D. Harrison, T.S. Clarke and C. Benson. 1992. Surficial glaciology of Jakobshavns Isbræ, West Greenland: Part II. Ablation, accumulation and temperature. J. Glaciol., 38(128), 169-181.

Ekström, G., M. Nettles and V.C. Tsai. 2006. Seasonality and increasing frequency of Greenland glacial earthquakes. Science, 311(5768), 1756-1758.

Fausto, R.S., C. Mayer and A. Ahlstrøm. 2007. Satellite-derived surface type and melt area of the Greenland ice sheet using MODIS data from 2000 to 2005. Ann. Glaciol., 46, 35-42.

Gregory, J.M., P. Huybrechts and S.C.B. Raper. 2004. Threatened loss of the Greenland ice-sheet. Nature, 428(6983), 616.

Haefliger, M., K. Steffen and C. Fowler. 1993. AVHRR surface temperature and narrow-band albedo comparison with ground measurements for the Greenland ice sheet. Ann. Glaciol., 17, 49-54.

Hall, D.K., R.S. Williams, Jr and K.A. Casey. 2006. Satellite-derived, melt-season surface temperature of the Greenland Ice Sheet (2000-2005) and its relationship to mass balance. Geophys. Res. Lett., 33(11), L11501. (10.1029/2006GL026444.)

Hanna, E. and J. Cappelen. 2003. Recent cooling in coastal southern Greenland and relation with the North Atlantic Oscillation. Geophys. Res. Lett., 30(3), 1132. (10.1029/2002GL015797.)

Hanna, E., T. Jónsson and J.E. Box. 2004. An analysis of Icelandic climate since the nineteenth century. Int. J. Climatol., 24(10), 1193-1210.

Hanna, E., P. Huybrechts, I. Janssens, J. Cappelen, K. Steffen and A. Stephens. 2005. Runoff and mass balance of the Greenland ice sheet: 1958-2003. J. Geophys. Res., 110(D13), D13108. (10.1029/2004JD005641.)

Howat, I.M., I.R. Joughin and T.A. Scambos. 2007. Rapid changes in ice discharge from Greenland outlet glaciers. Science, 315(5818), 1559-1561.

Huff, R. and K. Steffen. 2006. Large scale atmospheric circulation and melt variability on the Greenland Ice Sheet. Eos 87(52).

Hurrell, J.W. 1995. Decadal trends in the North Atlantic Oscillation: regional temperature and precipitation. Science, 269(5224), 676-679. 
Intergovernmental Panel on Climate Change (IPCC). 2007. Summary for policymakers. In Solomon, S. and 7 others, eds. Climate change 2007: the physical science basis. Contribution of Working Group I to the Fourth Assessment Report of the Intergovernmental Panel on Climate Change. Cambridge, etc., Cambridge University Press.

Janssens, I. and P. Huybrechts. 2000. The treatment of meltwater retardation in mass-balance parameterizations of the Greenland ice sheet. Ann. Glaciol., 31, 133-140.

Johannessen, O.M., K. Khvorostovsky, M.W. Miles and L.P. Bobylev. 2005. Recent ice-sheet growth in the interior of Greenland. Science, 310(5750), 1013-1016.

Jónsson, T. and H. Garðarsson. 2001. Early instrumental meteorological observations in Iceland. Climatic Change, 48(1), 169-187.

Joshi, M., C. Merry, K. Jezek and J. Bolzan. 2001. An edge detection technique to estimate melt duration, season and melt extent on the Greenland ice sheet using passive microwave data. Geophys. Res. Lett., 28(18), 3497-3500.

Joughin, I., W. Abdalati and M.A. Fahnestock. 2004. Large fluctuations in speed of Jakobshavn Isbræ, Greenland. Nature, 432(7017), 608-610.

Key, J. and M. Haefliger. 1992. Arctic ice surface temperature retrieval from AVHRR thermal channels. J. Geophys. Res. 97(D5), 5885-5893.

Krabill, W. and 9 others. 2000. Greenland Ice Sheet: highelevation balance and peripheral thinning. Science, 289(5478), 428-430.

Krabill, W. and 12 others. 2004. Greenland Ice Sheet: increased coastal thinning. Geophys. Res. Lett., 31(24, L24402). (10.1029/ 2004GL021533.

Luthcke, S.B. and 8 others. 2006. Recent Greenland ice mass loss by drainage system from satellite gravity observations. Science, 314(5803), 1286-1289.

Mote, T.L. 1998a. Mid-tropospheric circulation and surface melt on the Greenland ice sheet. Part I: atmospheric teleconnections. Int J. Climatol., 18(2), 111-130.

Mote, T.L. 1998b. Mid-tropospheric circulation and surface melt on the Greenland ice sheet. Part II: synoptic climatology. Int. J. Climatol., 18(2), 131-145.

Nghiem, S.V., K. Steffen, R. Kwok and W.Y. Tsai. 2001. Detection of snowmelt regions on the Greenland ice sheet using diurnal backscatter change. J. Glaciol., 47(159), 539-547.

Oerlemans, J. 1991. The mass balance of the Greenland ice sheet: sensitivity to climate change as revealed by energy-balance modelling. Holocene, 1(1), 40-49.

Ohmura, A., M. Wild and L. Bengtsson. 1996. A possible change in mass balance of Greenland and Antarctic ice sheets in the coming century. J. Climate, 9(9), 2124-2135.

Platnick, S. and 6 others. 2003. The MODIS cloud products: algorithms and examples from Terra. IEEE Trans. Geosci. Remote Sens., 41(2), 459-473.

Richter-Menge, J.A. and 24 others. 2006. State of the Arctic Report. Seattle, WA, National Oceanic and Atmospheric Administration/Office of Oceanic and Atmospheric Research/Pacific Marine Environmental Laboratory. (NOAA OAR Special Report. NOAA/PMEL Contribution No. 2952.)

Rignot, E. and P. Kanagaratnam. 2006. Changes in the velocity structure of the Greenland Ice Sheet. Science, 311(5673), 986-990.
Rogers, J.C. 1997. North Atlantic storm track variability and its association to the North Atlantic Oscillation and climate variability of northern Europe. J. Climate, 10(7), 1635-1647.

Rowley, R.J., J.C. Kostelnick, D. Braaten, X. Li and J. Meisel. 2007. Risk of rising sea level to population and land area. Eos, $\mathbf{8 8}(9)$, 105, 107.

Shuman, C.A., K. Steffen, J.E. Box and C.R. Stearns. 2001. A dozen years of temperature observations at the Summit: central Greenland automatic weather stations 1987-1999. J. Appl. Meteorol., 40(4), 741-752.

Steffen, K. and J. Box. 2001. Surface climatology of the Greenland ice sheet: Greenland Climate Network 1995-1999. J. Geophys. Res., 106(D24), 33,951-33,964.

Steffen, K., S. Nghiem, R. Huff and G. Neumann. 2004. The melt anomaly of 2002 on the Greenland Ice Sheet from active and passive microwave satellite observations. Geophys. Res. Lett., 31(20), L20402. (10.1029/2004GL020444.)

Steffen, K., N. Cullen and R. Huff. 2005. Climate variability and trends along the western slope of the Greenland Ice Sheet during 1991-2004. In Proceedings of the 85th Annual Meeting of the American Meteorological Society, San Diego, CA, January 9-13, 2005. Boston, MA, American Meteorological Society.

Steffen, K., J.H. Zwally, J.A. Rial, A. Behar and R. Huff. 2006. Climate variability, melt-flow acceleration, and ice quakes at the western slope of the Greenland Ice Sheet. Eos 87(52), Fall Meet. Suppl.

Stroeve, J. and K. Steffen. 1998. Variability of AVHRR-derived clearsky surface temperature over the Greenland ice sheet. J. Appl. Meteorol., 37(1), 23-31.

Sugden, D.E. and B.S. John. 1976. Glaciers and landscape; a geomorphological approach. London, Edward Arnold.

Thomas, R. and 7 others. 2001. Mass balance of higher-elevation parts of the Greenland ice sheet. J. Geophys. Res., 106(D24), 33,707-33,716.

Thompson, D.W.J., S. Lee and M.P. Baldwin. 2003. Atmospheric processes governing the Northern Hemisphere Annular Mode/ North Atlantic Oscillation. In Hurrell, J.W., Y. Kushnir, G. Ottersen and M. Visbeck, eds. The North Atlantic Oscillation: climatic significance and environmental impact. Washington, DC, American Geophysical Union, 81-112. (Geophysical Monograph Series 134.)

Velicogna, I. and J. Wahr. 2006. Acceleration of Greenland ice mass loss in spring 2004. Nature, 443(7109), 329-331.

Wan, Z., Y. Zhang, Q. Zhang and Z.L. Li. 2002. Validation of the land-surface temperature products retrieved from Terra Moderate Resolution Imaging Spectroradiometer data. Remote Sens. Environ., 83(1-2), 163-180.

Weidick, A. 1995. Greenland, In Williams, R.S., Jr and J.G. Ferrigno, eds. Satellite image atlas of glaciers of the world. US Geol. Surv. Prof. Pap. 1386-C, C1-C93.

Williams, R.S., Jr and D.K. Hall. 1993. Glaciers. In Gurney, R.J., J.L. Foster and C.L. Parkinson, eds. Atlas of satellite observations related to global change. Cambridge, Cambridge University Press, 401-422.

Zwally, H.J., W. Abdalati, T. Herring, K. Larson, J. Saba and K. Steffen. 2002. Surface melt-induced acceleration of Greenland ice-sheet flow. Science, 297(5579), 218-222.

Zwally, H.J. and 7 others. 2005. Mass changes of the Greenland and Antarctic ice sheets and shelves and contributions to sealevel rise: 1992-2002. J. Glaciol., 51(175), 509-527. 